\title{
Supervisory Pattern of Microteaching for SEA TEACHER Program: Student Perception
}

\author{
Palupi Sri Wijayanti ${ }^{1, *}$, Juang Kurniawan Syahruzah², Septian Aji Permana ${ }^{3}$, Supri Hartanto ${ }^{3}$, \\ Esti Setiawati $^{4}$

\begin{abstract}
${ }^{1}$ Department of Mathematics Education, Faculty of Teacher Training and Education, Universitas PGRI Yogyakarta, Indonesia ${ }^{2}$ Department of English Education, Faculty of Teacher Training and Education, Universitas PGRI Yogyakarta, Indonesia ${ }^{3}$ Department of Civic Education, Faculty of Teacher Training and Education, Universitas PGRI Yogyakarta, Indonesia

${ }^{4}$ Social Education Post Graduate Program, Universitas PGRI Yogyakarta, Indonesia
\end{abstract}

Received July 13, 2020; Revised September 8, 2020; Accepted September 29, 2020

\section{Cite This Paper in the following Citation Styles}

(a): [1] Palupi Sri Wijayanti, Juang Kurniawan Syahruzah, Septian Aji Permana, Supri Hartanto, Esti Setiawati , "Supervisory Pattern of Microteaching for SEA TEACHER Program: Student Perception," Universal Journal of Educational Research, Vol. 8, No. 11B, pp. 5824 - 5832, 2020. DOI: 10.13189/ujer.2020.082216.

(b): Palupi Sri Wijayanti, Juang Kurniawan Syahruzah, Septian Aji Permana, Supri Hartanto, Esti Setiawati (2020). Supervisory Pattern of Microteaching for SEA TEACHER Program: Student Perception. Universal Journal of Educational Research, 8(11B), 5824 - 5832. DOI: 10.13189/ujer.2020.082216.

Copyright $\bigcirc 2020$ by authors, all rights reserved. Authors agree that this article remains permanently open access under the terms of the Creative Commons Attribution License 4.0 International License

\begin{abstract}
The purpose of this study is to determine student perceptions in the process of supervising the implementation of teaching practices in ASEAN countries. The supervision process referred to is the Pattern of supervision and intensity of monitoring. This research is descriptive. The research variables consisted of three variables, namely the design of guidance, a concentration of advice, and time of supervision. The research population is students practicing teaching programs in ASEAN countries from 2017 to 2019 , while the research sample is students practicing from mathematics education courses and elementary teacher education. Data collection techniques were done by questionnaire, documentation, and interview - data analysis techniques using qualitative analysis and quantitative analysis. Qualitative data analysis will describe the categorization of patterns of supervision and intensity, while quantitative data analysis will show the classification of these variables. The results of the study show that students' perceptions of the Pattern of supervision for microteaching in the SEA-Teacher Program are generally good. It is characteristic visible from the importance of the existence and role of the mentor, the scope of supervision aspects was considered comprehensive, the scheduled time structure, and varied supervision methods.
\end{abstract}

Keywords Supervision Pattern, SEA Teacher,
Microteaching, Perception

\section{Introduction}

PGRI University Yogyakarta has a faculty of teachers and educational sciences that has a mission vision always to be active in contributing to providing the needs of qualified and competent faculty. Facilitating students to have professional teacher competencies, PPL II (Field Practice Program II), or so on is called microteaching. Microteaching can contribute to the development of teaching skills for pre-department teacher students. The results of other studies indicate that microteaching has an indispensable role in developing the skills of pre-service teachers [1]. As a student of the Faculty of Teacher Training and Education, the stage of the field experience program (microteaching) is crucial to equip the student in his preparation to become a qualified teacher.

Essential skills delivered in microteaching include presentation and reinforcement in teaching. Activities in microteaching accommodate learning situations in the classroom, which are almost the same as reality to develop abilities and facilitate in gaining in-depth knowledge about the art of teaching [2]. Reinforced by various opinions 
stating that microteaching is an effective way for pre-service students to provide an understanding of the meaning of education, develop teaching skills, and steps in helping students with learning difficulties. This program was organized to raise awareness of microteaching participants to essential components in teaching-learning activities as well as encourage them to be able to carry out lecture assignments and improve personal skills as creative teachers [3]. Microteaching participants were taught how to make the most effective choices when facing challenging situations in the classroom. They were also taught how to balance their role as modern teachers, from being instructors, creators, managers, mentors, to role models. Besides, with microteaching, students not only learn and reflect on various learning steps or strategies but can also add practical experience.

In general, microteaching provides an opportunity for students to get to know the realm of teacher training before actually engaging in teaching at school or as a teacher. It also explicitly prepares students to develop perceptions of unclear idealism by providing a realistic picture of the teaching situation [4]. Some of the benefits of microteaching include being able to provide insight for pre-service teachers to practice specific teaching strategies in a comfortable setting of the laboratory situation. It also gives them the freedom to receive clear and detailed feedback to strengthen their educational skills [3].

Microteaching facilitates students to master four main competencies as a professional teacher, namely educational, personality, professional, and social skills. A skilled teacher is a teacher who accommodates various facilities to become quality and has integrity. They should not only provide teaching and learning but must also strive to improve their abilities in multiple lines of life or science. That is because of the changing times that are so fast that they must be able to keep abreast of developments and learning that is more facilitated [5]. The flexible time and facility support in the supervision process for pre-service teacher students to innovate in implementing learning strategies to develop their pedagogical competencies [6].

The supervise process was directed to facilitate students in preparing practicum in microteaching more precisely under the achievement indicators that students must achieve. In general, this supervision requires students to organize various administrations that should be owned by teachers. This goal directly wants to create prospective students who have professional competencies. Furthermore, supervision before entering the microteaching practicum room, students will be informed to manage and organize the class so that there is a discussion between students in the learning process [7]. This activity directs them to have social competence. Also, supervision aims to provide experience to students in how to communicate and discipline themselves in acting as teachers. It is a manifestation of the competence of the teacher personally. Supervision conducted during the SEA-Teacher program was expected to provide services to students in improving their skills and training to be more confident so that they can practice teaching in ASEAN Countries well.

In the learning process, activities, including microteaching, is also required various completeness that supports success. Similarly, supervision activities were carried out between prospective teacher students and guidance lecturers, so all supervision needs must even be met both in terms of technical, infrastructure facilities, and activity management. To measure the success of supervision during the implementation of microteaching not only rests on the results of cognitive practice but can also measure through the level of student satisfaction during the supervised process. This student assessment was further referred to as by perception.

Education and learning obtained by students is one form of service to the community, where the service must have the qualifications that can provide satisfaction to the party that gets the benefit. Therefore, it is considered necessary if an activity is held evaluation action as a guideline for the value of the success of a workout. In this case, the activity in question is microteaching, while the service provided is supervised. This evaluation will be useful as a reference for improvement or assessment of further actions. One way to measure the success or supervision services assessment in microteaching activities that have taken place is to involve students who participate in activities. These, namely, students participate in sea-teacher programs.

Through the collection of student perception, data will be measured by the success rate of supervision. From the data of student perception obtained, it will be known the assessment and satisfaction level of students as participants of the SEA-TEACHER program, which is seen based on the perception of students, thus to see the profile of student perception in the implementation of supervision for microteaching in the SEA-Teacher program. Then researchers conducted a study that focused on the student's perception of the supervisory Pattern of the guidance lecturer on microteaching activities for the SEA-Teacher program.

Each type of practical modality will have its strengths and weaknesses [8] as well as the implementation of microteaching so far have several flaws. Defects in microteaching include (a) the use of peers as students, will be felt like a "farce" so that no good learning situation was realized; Assessment of the aspects of peers is presented based on how students' perceptions about the dynamics of student activities in discussion forums in the practicum room, or the dynamics of other academic activities [9]; (b) Repeated training using students and the same material can lead to burnout; (c) the supervisor by a supervisor without involving the school teacher is deemed incompatible with the reality of the school, and (d) debriefing that was only done once felt the material was still lacking. In general, microteaching participants are classmates. They already know in advance about the content that will be practiced in 
microteaching. It has become one of the difficulties for pre-service teacher students to identify problems that might arise in the real school environment [10]. These weaknesses require serious solutions to make the quality of microteaching closer to reality in schools so that the teaching experience of pre-service teacher students increases.

In the context of this study, the weaknesses of conventional microteaching practices, systems, models need to be developed into current systems and models. An independent method for implementing procedures needs to be developed into a collaboration system with partner schools. The microteaching model with peer students also needs to be developed. This requires pre-service teachers to show the peers of their skills in teaching their peers, and the supervisor will guide and suggest steps in improving teaching skills [11]. The effort was carried out by testing a new model in the practice of microteaching, namely microteaching, by a real student. This model is carried out through a system of collaboration with partner secondary schools so that students in teaching practice are total. With this model, it was expected that the learning situation would be as healthy as in school and be able to encourage students to prepare themselves more seriously and steadily. Moreover, supervisors who are also carried out by the teacher will be able to increase embarrassment to the practitioner if they do not master the material and necessary teaching skills. Based on the problems and arguments for solution efforts as intended, this development research was conducted.

Although microteaching provides many benefits for students, it is not uncommon to find challenges in the practice of its implementation. One of the main problems is the lack of adequate supervision from teachers and supervisors. Not all teachers and supervisors who are given the task of accompanying prospective teachers have the time, ability, and even the willingness to supervise pre-service teacher students, either as examples or advisors or as reliable advice providers when practicing in class. For this reason, it is necessary to conduct a study related to the implementation of mentoring for students who will practice teaching in ASEAN countries. It is, in the future, referred to as an analysis of students' perceptions of the supervision process in the implementation of teaching practices in ASEAN countries. This study aims to provide supervision maps in the form of supervision patterns and supervision intensity.

\section{Literature Review}

This section will discuss the libraries that were reviewed in such a way that it can be used to be the basis of reference in the determination of indicator variable research. Some of the things that are focused and basic in doing this research are microteaching, perception, and supervision.

\subsection{Microteaching}

By definition, microteaching is one of the approaches or ways to practice teaching performance in simple situation. Another opinion revealed that microteaching is a technique that is used to train student teachers in a minimized and restricted or artificial teaching environment. Microteaching simulations are carried out in classrooms with students formed in groups [12]. Another understanding states that microteaching is a pre-service teacher's teaching practice for a reduced time and class size in front of his / her peers and the mentors, tutors or, professors under their supervision. From some of these meanings, it can be concluded that microteaching is a teaching practice carried out by prospective teachers or teachers to hone teaching skills by summarizing the activities of learning to be simpler both in terms of time, students and learning.

The purpose of microteaching is to facilitate the improvement of teaching skills for prospective teachers and teachers through a simplified training process. Academics revealed an increase in pre-service teachers' competence in lesson planning, communication skills, and class management. Besides these, some competencies such as audiovisual material construction, subject matter knowledge, assessment methods, questioning skills, student motivation, and self-reflection when they had carried out microteaching [13][2][14]. The more specific goals are to train necessary teaching skills. The other skils are to facilitate prospective teachers to have professional readiness, reduce each training process part by part, to find out the level of strengths and weaknesses they have, and to improve and improve the skills that need to be improved. Also, the elements to achieve good practical quality were discussed in the pre-service students. As such, there will be many identification systems primarily that implement steps and interpretations of conformity as well as satisfaction [15].

Necessary integrated teaching skills are the various basic teaching skills that need to be taught to students when practicing microteaching. Teaching skills are already a form of integration of several teaching skills, ranging from the expertise of preparing lesson plans (RPs) to the capabilities of the learning process. Each of these skills can be explained as follows. (1) Skills in Preparing Lesson Plans (RP). Skills were trained when students will prepare microteaching practices. This is included in the planning stage related to teaching skills, behavior, and evaluation standards planned by pre-service teachers during microteaching. This stage also requires pre-service teachers to present their lesson plans and teaching activities for microteaching [16]. Furthermore, the skills that are trained include: (a) formulating essential competencies, (b) determining the subject matter, (c) integrating learning experiences with contextual teaching and learning insight, (d) integrating life skills in the subject matter, (e) formulating achievement indicators, (f) formulating assessment tools, (g) determining learning tools and media, 
(h) planning learning scenarios. (2) Teaching Skills. The skills that are practiced when students practice microteaching in the laboratory are: (a) opening and closing the lesson, (b) delivering the material, (c) carrying out the interaction of learning, (d) using the language of communication, appearance, motion, and time, and (e) carry out learning evaluations. Language becomes a significant problem for them in the delivery of subject matter because not all students have the ability to communicate in English when implementing the SEA TEACHER program in partner schools in ASEAN countries. It has an effect on their practical communication skills, empathy, and courtesy to students [6].

It was hoped that mastery of these two skills would enable the teacher to be able to manage to teach and learning activities well, effectively, efficiently to achieve learning goals, but also to please/satisfy both parties, both for the teacher and their students. An individual can assess all his efforts independently from other aspects related to the exercise that has been done [17]. The ability to manage such teaching and learning is a professional competency for teachers. Teacher competencies expected in the ASEAN community association was based on the framework of Southeast Asian teacher competencies. There are four categories, namely: 1) know and understand what I teach; 2) Help my students learn; 3) Engage the community; 4) Become a better teacher every day. The description of each category was explained in the figure below. [18]

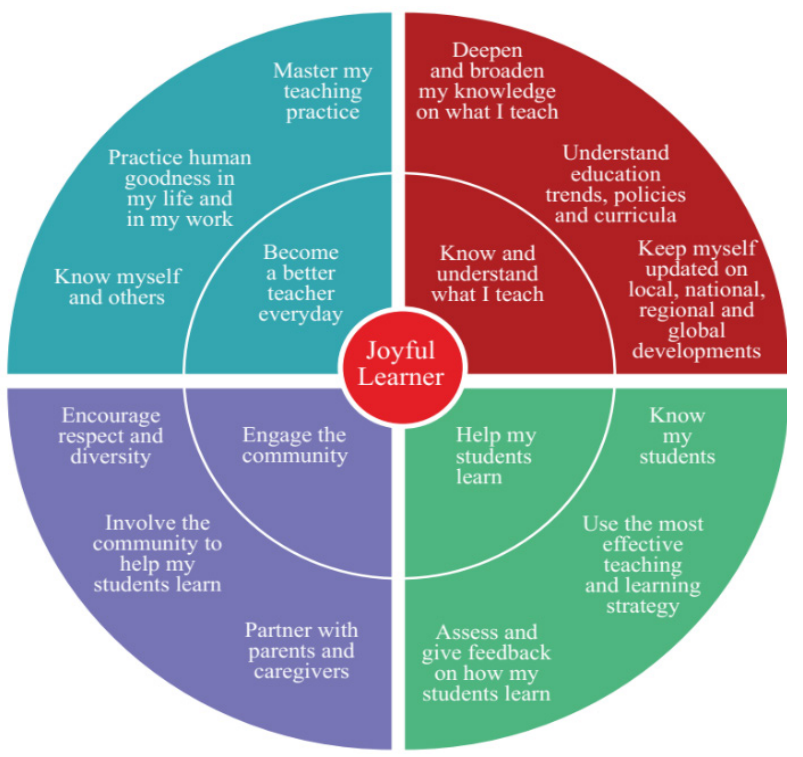

Figure 1. The Framework of Southeast Asia Teacher Competencies

Competency to be a teacher in ASEAN countries also has standards summarized in [19] which show the significant characteristics that define a "competent teacher" in Southeast Asia which relates to 1) pedagogical skills, 2) student performance assessment skills, 3) classroom management skills, and 4) professional development skills. In particular, based on the results of surveys and interviews, it shows that the right level of understanding can meet the needs of the joint and expectations of fellow professionals in improving pedagogical competence and positive developments in the practice of microteaching with peers [20]. In the next process, students will increasingly realize that the structure of the course and pedagogy contribute to their learning outcomes [21]. Not all the competencies of teachers taught in microteaching can be accepted entirely, precisely, and quickly in the process of supervising teaching practices in ASEAN countries. Thus, it is necessary to analyze the perceptions of students who take the microteaching supervision program.

\subsection{Perception}

Perception is the result of observing an object, an event that becomes an experience, or a relationship that is obtained by concluding information and translating messages. Perception can also be said as a personal view that he has related to real events that he has experienced. [22]. It is similar to a dictionary of Lexico, which states that perception is the ability to listen, see, and try to be more aware through the senses or how something is perceived, understood, or interpreted (www.lexico.com). Moreover, perception can be defined by awareness of the elements of the environment through physical sensation (www.merriam-webster.com). A perception is some mechanisms in which an individual represents the activities in which he is in the situation [23].

Besides, it argues that perception is interpreting, organizing, and interpreting stimuli received by someone so that it becomes meaningful and integrated into the individual. The process of perception includes three stages, namely, selection, organization, and interpretation [24]. It is supported by definition such as treatment or capability to understand and perceive through the senses or attention; insight; understanding (www.dictionary.com). Subjectively, perceptions under consciousness are usually subtle and continuous. Everything moves from one stage to the next and the movement of all other forms of change (while it is happening) without any sign of discontinuity [25]. Another opinion suggests that perception is defined as a process when someone organizes and interprets their sensory impressions to give meaning to their environment. Perception is caused by a combination of the context in which the individual was located and how he interacts with the environment [26].

Also, perception can be interpreted that perception is an individual's interpretation of the stimulus on an object or event that he obtained so that it becomes an experience for him. The perception of each individual can be very different, even if the things observed are the same. It can also be said that perception is the result of one's thoughts from certain situations. Statistically, there will be a significant difference in students' perceptions of their active involvement in learning [27]. 
Furthermore, students who always help their peers in preparing things for practicum can develop students' self-perceptions of pursuit competence [28]. In other words, perception is identified by the segmentation of experiences that continue to be meaningful [23]. Several things can affect perception, including hope. If sensory input is weak, noisy, or ambiguous, it can bias perception: change not only how well but even what is felt [29].

Recent research states about concise manner statistics in perception. These showed the emphasis on the critical role of perception in objects, views, and high-level social perception [30]. Learning that is based on the experience gained will be an investment in increasing learning motivation, self-perception, self-confidence, and practical skills [31].

Supervision on microteaching practice is carried out by Microteaching lecturers and supervisors based on the Dean Decree. The supervision material includes teaching preparation, preparing a Learning Preparation Plan (RPP), and practice. Supervision is carried out through lectures (regular) in the microteaching room. Microteaching facilitates professional supervision by accommodating constructive feedback, and the feedback provided can play an essential role in developing pre-service teacher skills to add reflective teaching experience [32].

A recent Canadian study looked at pressures related to limited space and time, concerns about challenging pre-service teachers, and decreased flexibility associated with making pre-service teachers a significant obstacle in supervision [33]. One reason students avoid supervision is that it is possible to avoid conflict [34].

\subsection{Supervision}

Supervision on teaching practice is carried out in structured supervision. Usually, a large number of pre-service students, the time spent indoors, and the tightness of students of higher teaching practices need to develop an automatic supervision system to facilitate students in providing healthy and productive practice facilities for students, lecturers, and implementing staff [35]. The intended structured supervision is a form of professional supervision given to pre-service teachers based on their needs through a regular cycle immediately after teaching practice. The effectiveness of supervision can be reached by the solution from several limitations in implementation [36]. This was explicitly finished by face to face for all the pre-service teacher. This supervision was realized in the form of face-to-face relationships between supervisors and teacher candidates who are practicing. The relationship between lecturers as supervisors and students will be more reliable when the lecturer recognizes the efforts of students by creating a perception of support [37]. Assumptions that are the reason for the need for supervision of microteaching are: (1) Teaching is a very complex activity that requires acute observation and analysis. Through this observation and analysis, supervisors will efficiently develop the ability of teachers in learning practices. (2) Professional teachers who want to be prepared want collegial rather than authoritarian ways.

One of the main objectives in supervision is to assess the suitability of the subject matter with the learning planned and outlined in the lesson plan [4]. Besides, sometimes, students still feel a lack of confidence to engage in direct teaching practices at school for some reason. Theoretically, self-confidence in supervising has become a topic in some speculations [38]. Pre-service teachers assume that they are still not ready to practice teaching in partner schools. Some of the reasons are because they think that they do not have enough knowledge about lesson planning and practicum portfolios and have problems relating to classroom management. Besides, they believe that it will be challenging to hold time management to be efficient. It similar with some feel that fear to the ignorance of coordination the teacher's plan. These are caused by some affects such as lack of equipment in partner school, lack of adequate supervision, and limited opportunities to make a good practice [7]. Student's fears with teaching practice can be reduced by supporting lecturers. It is as supervisors in the observation process to assess microteaching. That has an aim in order to the students do not need to hesitate to play an active role in every microteaching process [10].

\section{Methods}

This type of research is a descriptive qualitative study that seeks to reveal the Pattern of implementation of the UPY SEA-Teacher program for Mathematics Education Study Programs and PGSD Study Programs from 2017 to 2019 according to students' perceptions. The study was conducted by a survey of students practicing the UPA SEA-Teacher program. The research variables consist of two types, namely: (1) the Pattern of supervision, including aspects of the role of the mentor, the scope of the supervision aspect, the supervision method, and the time structure of the management and (2) the intensity of the supervision, including the frequency of mentoring of the supervisor, the level of usefulness of the supervision process, and the level of effectiveness of the supervision process.

The sample of this study is the students practicing the UPY SEA-TEACHER program that began from 2017 to 2019. They are students from mathematics education and elementary teacher education courses. This research will be conducted at the Yogyakarta PGRI University Faculty of Teacher Training and Education in the Mathematics Education Study Program and PGSD Study Program. This research was done in the beginning semester of the 2019/2020 school year.

The instruments used in the study were questionnaires, documentation, and interviews. This questionnaire 
instrument was used to reveal student's perceptions of data on practices of the implementation of the SEA-Teacher UPY program for students in the Mathematics Education Study Program and PGSD Study Program in 2017 to 2019, which included aspects of Pattern and intensity of supervision. Documentation instruments to dig up information about the supervision notes by the supervisor in the implementation of the SEA-Teacher program, student notebooks, work program matrices, and others. Interview instrument to confirm and complete the documented data and questionnaire results, interviews were conducted on students who were randomly drawn.

Data analysis techniques used in this study are qualitative and quantitative data analysis. Qualitative data analysis was used to confirm student's perceptions of the Pattern of supervision and intensity of supervision. In contrast, Quantitative Data analysis was used to clarify and confirm the results of qualitative data analysis by showing the percentage of the implementation of the UPY SEA-Teacher program for Mathematics Education Study Programs and PGSD Study Programs in 2017 until 2019.

\section{Results and Discussion}

After using the method of dissing, the results of the study were obtained. The results of research related to the Pattern of supervision are obtained. The Pattern of supervision, which is the focus of the study, is divided into six aspects. These aspects are attendance, role, completeness, methods used, duration, and mentor schedule.

\subsection{The Existence of a Mentor}

In preparing students to interact off-campus as in partner schools in teaching programs in ASEAN Countries, the supervisors who help direct students to prepare themselves physically and mentally were determined. Supervised lecturers should monitor and facilitate their students to obtain proper provision in teaching. The appointed supervisors come from each student study program to maintain scientific linearity that is suitable for the students of the practice. In addition to the supervisor, some supervisors or tutors are tasked with helping direct students in partner schools to apply theories in learning in indoor and outdoor classes.

Based on the results of data collection that has been done, the results are obtained that $70 \%$ of the students feel very agree while $30 \%$ of other respondents agreed to the existence of a supervisor. This means that the life of a supervisor can provide input and essential provisions for students to carry out teaching practice programs in ASEAN countries. Besides, the presence of supervisors can facilitate students who are feeling confused or hesitant in preparing themselves for teaching practice. Research results obtained by O'donovan, Clough, and Petch (2017) state that supervisors can provide positive energy for conduct evaluation in microteaching and still convey that they have received changes in practice [36].

\subsection{The Role of the Supervisor}

The existence of the supervisor is felt to be beneficial so that the role given by the supervisor can be handled. There are only $10 \%$ of respondents who stated that the part of the supervisor was not appropriate in preparing themselves for teaching practices in ASEAN countries, $20 \%$ of the respondents agreed they had given a perfect and proper role. While the majority, namely, $70 \%$ of respondents, said that the part of the supervisor has been excellent and appropriate to be able to provide provisions by the competencies that must be mastered. Based on the results of research conducted by Akram et. all (2018) mentioned that the Supervisor, in this case, is the supervisor who should be able to train and support students to increase their belief and commitment to learning [37].

\subsection{Coverage Aspects of the Supervision}

The implementation of mentoring conducted by the supervisor has included completeness in the aspects of planning, implementation of supervision, and program evaluation in each consultation. Most respondents stated that the supervision and enforcement of the discussion had covered all aspects of $70 \%$. In comparison, $30 \%$ of the other respondents said that there was incomplete supervision in terms of planning, implementing, and evaluating the program. The scope of the complete planning aspects includes matters relating to an administration that must be prepared by students before practicing teaching practices in ASEAN countries. The elements of implementation include issues related to the monitoring of the performance of the supervision and consultation program in improving the ability to have the competence to teach in ASEAN countries. The scope of the material in the implementation of the evaluation includes matters relating to feedback from students who want a better confirmation, including the more synergistic and scheduled mentoring process. The results of research conducted by Sujadi, Kongsoonoen, Perdana, et al. (2018) states that based on the results obtained, students will follow up on the feedback given by the supervisor regarding the deficiencies they have during practice. Furthermore, they will be disciplined using the feedback given and then discuss with other SEA-Teacher project participants [39].

\subsection{Supervision Method}

The Pattern of coaching is also seen based on aspects of the coaching process that are carried out varying, discussion, and individually. Based on data analysis, the supervision process has been carried out then modified as 
indicated by $60 \%$ data, $20 \%$ group discussion, and $20 \%$ individual counseling. It makes students feel comfortable because the mentoring process has altered. Besides, the coaching process carried out in group discussions can provide additional insights to solve problems together. In contrast, the coaching process carried out individually can increase student confidence in preparing himself for teaching practices in ASEAN countries. Based on the results of research by Darwanis (2016), the supervision carried out was very influential in providing experience to compile an orderly administration. It aims to improve the ability as a student-teacher candidate during the various supervision processes [40].

\subsection{The Time Structure of the Supervision Implementation}

The Pattern of coaching is also seen from the aspect of scheduling the coaching process and synergizing with the teaching practice needs of students in ASEAN countries. The data from all the respondents show that the majority of student $(80 \%)$ agree and satisfied with the theory of microteaching program. While $20 \%$ of respondents said that it was not under the needs of the country they were going to. It is related to several kinds of environments around the school that can be used as media in the learning process. Research results obtained from Yusof, Mohd, and Jafaar (2014) state that the environment in a career as a teacher can provide opportunities for students to develop their talents and display abilities in the art of teaching and solving teaching problems [41].

\subsection{Supervision is Not Scheduled Yet, But According to the Needs between Lecturers and Students}

The Pattern of supervision that was carried out was also seen in the aspect of scheduling supervision. In the supervision process, the majority or $70 \%$ of respondents said that they were not scheduled. While $30 \%$ of respondents said they were recorded. It is because some activities have not been synchronized on the part of student students and supervisors. Even so, the implementation of the supervision continues with the Pattern agreed upon by the student students and the supervisor. The response given by Martin, Stamper, Flowers (2020) states that the results of their study show that time is a challenge to manage competencies, so that they will continue to discipline themselves and arrange a schedule in processing themselves [42].

Analysis of student perceptions that aims to determine the Pattern and intensity of teaching practice program supervision in ASEAN countries is included in both categories. Evidenced by the data that shows the trend, most agree or say good.

\section{Conclusions}

The results showed that the students 'assessment, which was summarized in the students' perceptions of the microteaching supervision pattern in the SEA-Teacher Program, was generally categorized as either good. The category was adjusted to the results of research on the aspect of the existence of the supervisor and their role when supervise. Besides, another element is that the provision of supervision by the supervisor has met the scope of the mentoring process and is considered comprehensive. Another part of perception is the time structure of mentoring that has been well scheduled, and the methods used in each supervision have varied.

Based on the results of this study, it is recommended that the implementation of microteaching for the SEA-Teacher program be provided with a manual that contains at least two languages in both English and Indonesian. This is so that students can simultaneously practice understanding the rules in the microteaching guide in international languages. Furthermore, in the microteaching supervision process, an introduction to the curriculum applied by ASEAN countries, which is the goal of teaching practice, is also required so that students can adjust their learning plans according to the curriculum used.

\section{Acknowledgments}

We are very grateful to experts for their appropriate and constructive suggestions to improve this template. The author acknowledges the professional and financial support of the Institute of Research and Community Services Universitas PGRI Yogyakarta, Ajib Team of University, the coordinator of the SEA-Teacher project, and the pre-service teacher. They were involved in microteaching of the SEA-Teacher program.

\section{REFERENCES}

[1] B. A. Danday, "Active vs. Passive microteaching lesson study: Effects on Pre-service Teachers' Technological Pedagogical Content Knowledge," Int. J. Learn. Teach. Educ. Res., vol. 18, no. 6, pp. 181-200, 2019, doi: 10.26803/ijlter.18.6.11.

[2] A. Remesh, "Microteaching, an efficient technique for learning effective teaching," J. Res. Med. Sci., vol. 18, no. 2, pp. 158-163, 2013.

[3] B. B. C. Onwuagboke, R. C. Osuala, and R. C. Nzeako, "The Impact of microteaching in developing teaching skills among pre-service teachers in Alvan Ikoku College of Education Owerri, Nigeria," African Res. Rev., vol. 11, no. 2, p. 237, 2017, doi: 10.4314/afrrev.v11i2.18. 
[4] G. A. Wilkinson, "Enhancing microteaching through additional feedback from preservice administrators," Teach. Teach. Educ., vol. 12, no. 2, pp. 211-221, 1996, doi: 10.1016/0742-051X(95)00035-I.

[5] H. Nafis, Rusdinal, A. Ananda, Khairani, and H. Satria, "Influence of profesional teacher competence, self concept, interest learning, and early to learning outcomes mathemathics," Int. J. Innov. Technol. Explor. Eng., vol. 8, no. 10 , pp. 3857-3862, 2019, doi: 10.35940/ijitee.J9893.08 81019 .

[6] I. Sujadi, A. N. Wulandari, and I. Kurniawati, "Pre-service teachers' perspectives: pedagogical challenges of teaching mathematics on Sea-Teacher project," J. Phys. Conf. Ser., vol. 1321 , no. 3, 2019, doi: 10.1088/1742-6596/1321/3/032 124.

[7] K. Fish, J. Mun, and R. A'Jontue, "Microteaching experience in distance English Language teacher training: a case study," J. Educ. Online, vol. 13, no. 1, pp. 194-217, 2015, [Online]. Available: https://www.thejeo.com/archive/ archive/2016 131/fishmunajontuepdf.

[8] J. Olson, J. Rinehart, J. J. Spiegel, and L. Al-Nakkash, "Student perception on the integration of simulation experiences into human physiology curricula," Adv. Physiol. Educ., vol. 43, no. 3, pp. 332-338, 2019, doi: 10.1152/advan.00202.2018.

[9] W. N. E. Saputra, A. Supriyanto, B. Astuti, Y. Ayriza, and S. Adiputra, "The effect of student perception of negative school climate on poor academic performance of students in Indonesia," Int. J. Learn. Teach. Educ. Res., vol. 19, no. 2, pp. 279-291, 2020, doi: 10.26803/ijlter.19.2.17.

[10] S. Baştürk, "Investigating the effectiveness of microteaching in mathematics of primary pre-service teachers," J. Educ. Train. Stud., vol. 4, no. 5, pp. 239-249, 2016, doi: 10.11114 jets.v4i5.1509.

[11] V. K. Dayanindhi and S. P. Hegde, "Effectiveness of microteaching as a method of developing teaching competence among in-service medical teachers.," $J$. Adv. Med. Educ. Prof., vol. 6, no. 4, pp. 155-161, 2018, [Online]. Available:

http://www.ncbi.nlm.nih.gov/pubmed/30349826\%0Ahttp:// www.pubmedcentral.nih.gov/articlerender.fcgi?artid=PMC 6191834

[12] M. L. Hidayat, W. H. Prasetiyo, and J. Wantoro, "Pre-service student teachers' perception of using google classroom in a blended course," Humanit. Soc. Sci. Rev., vol. 7, no. 2, pp. 363-368, 2019, doi: 10.18510/hssr.2019.7242.

[13] Sentumbwe Nakkazi Damalie, "Student-Teachers' Experiences of Microteaching on an Economics Methods Course Sentumbwe," Int. Multi-disciplinary, vol. 12, no. 50, pp. 135-142, 2018, doi: http://dx.doi.org/10.4314/afrrev.v1 $2 \mathrm{i} 2.10$.

[14] H. Akkuş and S. Üner, "The Effect of microteaching on pre-service chemistry teachers' teaching experiences," Cukurova Univ. Fac. Educ. J., vol. 46, no. 1, pp. 202-230, 2017, doi: $10.14812 /$ cuefd. 309459 .

[15] N. F. Rosli, N. S. Rabe, and M. M. Osman, "Perception of quality of life among community in selangor," Plan. Malaysia, vol. 16, no. 2, pp. 12-20, 2018, doi: 10.21837/pmjournal.v16.i6.456.
[16] Z. Arsal, "The effects of microteaching on the critical thinking dispositions of pre-service teachers," Aust. J. Teach. Educ., vol. 40, no. 3, pp. 140-153, 2015, doi: 10.14221/ajte.2014v40n3.9.

[17] B. Pageaux, "Perception of effort in Exercise Science: Definition, measurement and perspectives," Eur. J. Sport Sci., vol. 16, no. 8, pp. 885-894, 2016, doi: 10.1080/17461391.2016.1188992.

[18] Innotech Seameo, Southeast Asia Teachers Competency Framework. 2018.

[19] P. Watson, Teaching Competency Standards In Southeast Asian Countries, vol. 1. 2005.

[20] T. T. Phuong, H. B. Duong, and G. N. McLean, "Faculty development in Southeast Asian higher education: a review of literature," Asia Pacific Educ. Rev., vol. 16, no. 1, pp. 107-117, 2015, doi: 10.1007/s12564-015-9353-1.

[21] T. J. Shaw, S. Yang, T. R. Nash, R. M. Pigg, and J. M. Grim, "Knowing is half the battle: Assessments of both student perception and performance are necessary to successfully evaluate curricular transformation," PLoS One, vol. 14, no. 1, pp. 1-13, 2019, doi: 10.1371/journal.pone.0210030.

[22] K. A. Aguirre-Raya, M. F. Castilla-Peón, L. A Barajas-Nava, V. Torres-Rodríguez, O. Muñoz-Hernández, and J. Garduño-Espinosa, "Self-perception and knowledge of evidence based medicine by physicians," BMC Med. Educ., vol. 16, no. 1, pp. 1-9, 2016, doi: 10.1186/s12909-016-0681-6.

[23] J. M. Zacks, "Event perception and memory," Annu. Rev. Psychol., vol. 71, no. 1, pp. 165-191, 2020, doi: 10.1146/annurev-psych-010419-051101.

[24] O. U. Qiong, “A Brief Introduction to Perception," Stud. Lit. Lang., vol. 15, no. 4, pp. 18-28, 2017, doi: 10.3968/10055.

[25] P. A. White, "Is conscious perception a series of discrete temporal frames?," Conscious. Cogn., vol. 60, no. January, pp. 98-126, 2018, doi: 10.1016/j.concog.2018.02.012.

[26] R. Bajcsy, Y. Aloimonos, and J. K. Tsotsos, "Revisiting active perception," Auton. Robots, vol. 42, no. 2, pp. 177 196, 2018, doi: 10.1007/s10514-017-9615-3.

[27] F. Martin, C. Wang, and A. Sadaf, "Student perception of helpfulness of facilitation strategies that enhance instructor presence, connectedness, engagement and learning in online courses," Internet High. Educ., vol. 37, no. January, pp. 52 65, 2018, doi: 10.1016/j.iheduc.2018.01.003.

[28] J. C. Núñez, B. Regueiro, N. Suárez, I. Piñeiro, M. L. Rodicio, and A. Valle, "Student perception of teacher and parent involvement in homework and student engagement: The mediating role of motivation," Front. Psychol., vol. 10, no. JUN, p. 1384, 2019, doi: 10.3389/fpsyg.2019.01384.

[29] F. P. de Lange, M. Heilbron, and P. Kok, "How Do Expectations Shape Perception?," Trends Cogn. Sci., vol. 22, no. 9, pp. 764-779, 2018, doi: 10.1016/j.tics.2018.06.002.

[30] D. Whitney and A. Yamanashi Leib, "Ensemble Perception," Annu. Rev. Psychol., vol. 69, no. 1, pp. 105-129, 2018, doi: 10.1146/annurev-psych-010416-044232.

[31] S. N. Abd Rahman, A. A. Samad, and N. A. Bakar, "Exploring learners' perception on improving their 
willingness to communicate in English through experiential learning among undergraduate students," Univers. J. Educ. Res., vol. 8, no. 1 A, pp. 62-69, 2020, doi: 10.13189/ujer.2020.081309.

[32] S. Wangchuk, "Effects of Microteaching on the Pre-S ervice Teachers ' Teaching Competence - A Case in Bhutan Sangay Wangchuk Royal University of Bhutan," Int. J. Educ. Dev. Using Inf. Commun. Technol., vol. 15, no. 1, p. 14, 2019, [Online]. Available:https://eric.ed.gov/?id=EJ121427 0 .

[33] M. Hall, C. Poth, P. Manns, and L. Beaupre, "An exploration of canadian physiotherapists' decisions about whether to supervise physiotherapy students: Results from a national survey," Physiother. Canada, vol. 68, no. 2, pp. 141-148, 2016, doi: 10.3138/ptc.2014-88E.

[34] J. Varland, E. Cardell, J. Koski, and M. McFadden, "Factors Influencing Occupational Therapists' Decision to Supervise Fieldwork Students," Occup. Ther. Heal. Care, vol. 31, no. 3, pp. 238-254, 2017, doi: 10.1080/07380577.2017.1328631.

[35] G. Marques and R. Pitarma, "An Internet of Things-based environmental quality management system to supervise the indoor laboratory conditions," Appl. Sci., vol. 9, no. 3, 2019, doi: 10.3390/app9030438.

[36] A. O’Donovan, B. Clough, and J. Petch, "Is Supervisor Training Effective? A Pilot Investigation of Clinical Supervisor Training Program," Aust. Psychol., vol. 52, no. 2, pp. 149-154, 2017, doi: 10.1111/ap.12263.

[37] A. Akram, M. Kamran, M. S. Iqbal, U. Habibah, and M. Atif
Ishaq, "The impact of supervisory justice and perceived Supervisor support on organizational citizenship behavior and commitment to supervisor: the mediating role of trust," Cogent Bus. Manag., vol. 5, no. 1, pp. 1-17, 2018, doi: $10.1080 / 23311975.2018 .1493902$.

[38] A. Thériault and N. Gazzola, "Dilemmas that undermine supervisor confidence," Couns. Psychother. Res., vol. 18, no. 1, pp. 14-25, 2018, doi: 10.1002/capr.12153.

[39] I. Sujadi, K. Kongsoongnoen, F. A. Perdana, I. Kurniawati, and A. N. Wulandari, "Strategy assessment as learning for developing pedagogical competence of Indonesian-Thailand mathematics student teachers," J. Phys. Conf. Ser., vol. 1028, no. 1, 2018, doi: 10.1088/1742-6596/1028/1/012136.

[40] D. Darwanis, "Effect of professionalism, competence, knowledge of financial management, and intensity guidance apparatus inspectorate for quality of financial statements (Study on Inspectorate Regencies/cities in Aceh)," Brand Res. Accounting, Negoc. Distrib., vol. 7, no. 1, pp. 28-36, 2016.

[41] R. Yusof, N. A. Mohd, and N. N. Jaafar, "Consistency of personality profiles with teaching career environment at specialist teacher education Institute Kuala Lumpur," Procedia - Soc. Behav. Sci., vol. 114, pp. 141-147, 2014, doi: 10.1016/j.sbspro.2013.12.674.

[42] F. Martin, B. Stamper, and C. Flowers, "Examining student perception of readiness for online learning: Importance and confidence," Online Learn. J., vol. 24, no. 2, pp. 38-58, 2020, doi: 10.24059/olj.v24i2.2053. 